\title{
Feed Enrichment with Amylolytic Lactic Acid Bacteria to Stimulate the Growth of Freshwater Crayfish (Cherax quadricarinatus)
}

\author{
Dahlia $^{*)}$, Hasniar, Seniati, Ardiansyah, Andi Puspa Sari Idris, and Hartinah \\ Aquaculture Department, Pangkep State Polytechnic of Agriculture, \\ South Sulawesi, Indonesia. \\ ${ }^{*}$ Corresponding author: unga_dahlia@yahoo.co.id
}

Received: 11 December 2017; Accepted: 12 June 2018

\begin{abstract}
Dahlia, Hasniar, Seniati, Andi Puspa Sari Idris, Ardiansyah and Hartinah. 2018. Feed Enrichment with Amylolytic Lactic Acid Bacteria to Stimulate the Growth of Freshwater Crayfish (Cherax quadricarinatus). Aquacultura Indonesiana, 19 (1): 33-37. The goal of feed enrichment with amylolytic Lactic Acid Bacteria (LAB) was to get an optimal feed formula in stimulating the growth of freshwater crayfish (Cherax quadricarinatus). The research design used a completely randomized block design, which consists of 2 groups (Group I = probiotic HS7 with inoculum density $10^{8}$ and Group II = probiotic HS7 with density $10^{10}$ ). Each group were given 4 different treatment (Feed $\mathrm{A}=$ protein $50 \%$-carbohydrate 20\%; Feed $\mathrm{B}=$ protein $40 \%$ carbohydrate $30 \%$; Feed $\mathrm{C}=$ protein $30 \%$-carbohydrate $40 \%$; and Feed $\mathrm{D}=$ protein $20 \%$-carbohydrate $50 \%$ ), with 2 repetition. The parameter observed in this study was daily growth rate and absolute growth. The result showed that Feed C, composed by protein 30\%-carbohydrate $40 \%$ with LAB enrichment and inoculum density of $10^{8}$ gives the best growth, with daily growth rate of $\pm 0.22-0.23 \%$ each day and absolute growth of $\pm 13.10-13.20$ gram in 75 days.
\end{abstract}

Keywords: Amylolytic; Freshwater crayfish; Growth rate; LAB

\section{Introduction}

The main problems in cultivating freshwater crayfish (Cherax quadricarinatus) are its slow growth, therefore it takes around 6-7 months to get the proper size for consumption, and the production cost (feed) is relatively high since it contains high level of protein.

In lobster, rather than carbohydrate, protein is more effectively used as source of energy. This is caused by little activity of amylase enzyme in lobsters digestive tract compared to other animals and human. Therefore, it is important to increase the activity of amylase enzyme hence the using of protein as energy source could be reduced, and otherwise carbohydrate might be used. Protein is expected to be used for growth and replacing damaged cells, rather than be used as main source of energy (Aslamyah, 2006).

The solution that could be discussed and developed to tackle this problems are creating a good condition in freshwater crayfish's digestive tract to support the growth and development of non-pathogen microfloras, and increasing the activity of amylase enzyme in digestiva tract. This can be achieved by utilize a lactat acid-producing bacteria as bacteriocyn which can depress the growth of pathogen microfloras in digestive system.
Those bacterias are catergorixed as amylolytic Lactic Acid Bacteria (LAB), since it produces huge amount of amylase enzyme in the freshwater crayfish digestive tract (Hasniar and Dahlia, 2016).

Amylolytic lactic acid bacteria should be utilized in artificial feed to accelerate the growth of non-pathogen microfloras in mucous intestinal to stimulate the growth of freshwater crayfish.

The goal of this research was to get a highcarbohydrate feed formulation which is also enriched by amylolytic Lactic Acid Bacteria (LAB) probiotic which is effective in increasing the growth of freshwater crayfish.

\section{Materials and Methods}

This research was conducted from March to October 2016. Used materials are freshwater crayfish, 4-5 grams each, Lactic Acid Bacteria (LAB) that has been tested, and artificial feed. Used tools are a 60 liters glass aquarium, completed by a blower, net, scale, spectrophotometer, $\mathrm{pH}$ meter, and hand refractometer.

\section{Research Design}

The research design used a completely randomized block design, which consists of 2 groups (Group I = probiotic HS7 with inoculum 
density $10^{8}$ and Group II = probiotic HS7 with density $10^{10}$ ). Each group were given 4 different treatment: Feed $\mathrm{A}=$ protein $50 \%$-carbohydrate $20 \%$; Feed $\mathrm{B}=$ protein $40 \%$-carbohydrate $30 \%$; Feed $\mathrm{C}=$ protein $30 \%$-carbohydrate $40 \%$; and Feed $\mathrm{D}=$ protein $20 \%$-carbohydrate $50 \%$ ), with 2 repetitions.

\section{Feed Making}

The main ingredient was finely ground dried fish and the additional ones were flour, fish oil, binder, atractan, and vitamins. Feed was made into 4 types of composition:

A-1 $=$ protein $50 \%$-carbohydrate $20 \%+$ probiotic HS7 with inoculum density of $10^{8}$

A-2 $=$ protein $50 \%$-carbohydrate $20 \%+$ probiotic HS7 with inoculum density of $10^{10}$

B-1 $=$ protein $40 \%$-carbohydrate $30 \%+$ probiotic HS7 with inoculum density of $10^{8}$

B-2 $=$ protein $40 \%$-carbohydrate $30 \%+$ probiotic with inoculum density of $10^{10}$

$\mathrm{C}-1=$ protein $30 \%$-carbohydrate $40 \%+$ probiotic HS7 with inoculum density of $10^{8}$

$\mathrm{C}-2=$ protein $30 \%$-carbohydrate $40 \%+$ probiotic HS7 with inoculum density of $10^{10}$

D-1 $=$ protein $20 \%$-carbohydrate $50 \%+$ probiotic HS7 with inoculum density of $10^{8}$

D-2 $=$ protein $20 \%$-carbohydrate $50 \%+$ probiotic HS7 with inoculum density of $10^{10}$

However, the proximate analysis of the experimental feed was not conducted in the present study.

\section{Amylolytic Lactic Acid Bacteria Preparation}

$(L A B)$

Amylolytic LAB was cultured in MRSA medium, incubated within 24 hours in $30^{\circ} \mathrm{C}$ temperature. Next $0.1 \mathrm{~mL}$ was taken from this fresh culture and put into $10 \mathrm{~mL}$ MRSA medium and shaked within 24 hours. Each LAB was made with different level of density, which were $10^{8}$ and $10^{10} \mathrm{cfu} / \mathrm{mL}$. This culture was ready to be mixed with the feed.

\section{Feed Plus Amylolytic Lactic Acid Bacteria (LAB) Preparation}

The feeds (Feed A, B, C, and D) were enriched with probiotic bacteria by mixing the probiotic into eggwhite, homogenized and sprayed into the feed equally. There were two types of formulation made, which were feed $+\mathrm{LAB}$ with inoculum density of $10^{8}$ and feed+LAB with inoculum density of $10^{10}$. The feed was dried, then packed and labeled in a packaging, and stored in a freezer. The feed was then ready to be given to the crayfish. This preparation was done every week so the probiotic works efficiently.

\section{Feeding and Water Changing}

Feed was given 3 times a day, in the morning, middle of the day, and afternoon with $5 \%$ of biomass dose. Siphoning was done everyday to exfoliate the rest of the feed and the water was changed if necessary.

\section{Water Quality Observation}

The water quality parameters including $\mathrm{pH}$, and temperature were observed everyday at $8.00 \mathrm{am}$, while ammonia was observed weekly.

\section{Growth Rate Observation}

The growth rate was observed everyday by scaling certain amount of freshwater crayfish. The daily growth rate of individual was calculated by a formula of Effendie (1979) :

$$
\mathrm{DGR}=\frac{\mathrm{Wt}-\mathrm{Wo}_{0}}{\mathrm{~T}}
$$

When calculating the absolute growth rate, the following formula was used:

$$
\mathrm{W}=\mathrm{Wt}-\mathrm{Wo}_{\mathrm{o}}
$$

Where:

$$
\begin{array}{ll}
\mathrm{DGR} & =\text { daily growth rate }(\%) \\
\mathrm{W} & =\text { absolute weight growth }(\mathrm{g}) \\
\mathrm{Wo} & \text { initial weight of freshwater crayfish }(\mathrm{g}) \\
\mathrm{Wt} & =\text { final weight of freshwater crayfish }(\mathrm{g}) \\
\mathrm{T} & =\text { the duration of the feeding trial (days) }
\end{array}
$$

\section{Statistical analysis}

The data was analyzed using analysis of variance (ANOVA). Differences in the treatment were examined by Duncan double comparative test. Data analysis was used with Software Statistica release 5 (Statsoft, Inc.). The level of significance used for all tests was $\mathrm{P}<0.05$.

\section{Results}

The result of water quality parameters in the culture unit used for the experiment (Table 1) revealed that all parameters are in good condition to support the growth and survival of the experimental crayfish. Water temperature, $\mathrm{pH}$ and ammonia are in the (Table 1). Water temperature was between $26^{\circ} \mathrm{C}$ and $27^{\circ} \mathrm{C}$ during the experimental period, while the $\mathrm{pH}$ values 
were stable at above 7.3. The mean level of ammonia was below $0.3 \mathrm{ppm}$.

Table 1 . Water quality of culture units for the experimental crayfish

\begin{tabular}{lcc}
\hline Parameters & $\begin{array}{c}\text { Mean Values of } \\
\text { Group I }\end{array}$ & $\begin{array}{c}\text { Mean Values } \\
\text { of Group 2 }\end{array}$ \\
\hline Temperature & $26.0 \pm 0.33$ & $26.0 \pm 0.21$ \\
pH & $7.30 \pm 0.21$ & $7.30 \pm 0.32$ \\
Ammonia & $0.29 \pm 0.32$ & $0.29 \pm 0.39$ \\
\hline
\end{tabular}

The result of analysis of variance showed that the feed with various contents of protein and carbohydrate and enriched by lactic acid bacteria inoculum gives a significant effect $(\mathrm{P}<0.05)$ towards the growth of freshwater crayfish. The result of Duncan double comparative test shows that Feed $\mathrm{C}$ is significantly different $(\mathrm{P}<0.01)$ with other feeds (Feed A, B, and D) in increasing the daily growth rate and the absolute growth of
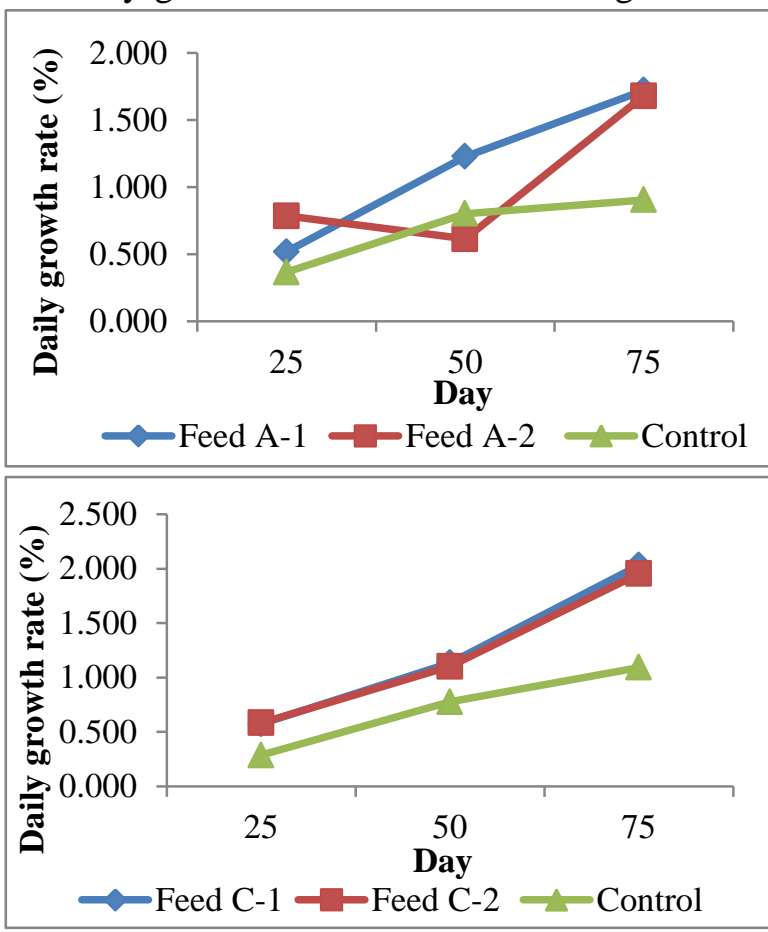

freshwater crayfish within 75 days cultivation. Feed A was not significantly different with Feed B, but Feed A and Feed B was significantly different $(\mathrm{P}<0.05)$ with Feed $\mathrm{D}$.

The feed given with different protein and carbohydrate which was enriched with lactic acid bacteria inoculum can affect the average weight increase and daily growth rate of freshwater crayfish. The daily growth rate of freshwater crayfish in 75 days cultivation can be seen in Figure 1.

In 75 days cultivation, freshwater crayfish which given feed $\mathrm{A}, \mathrm{B}, \mathrm{C}$, and $\mathrm{D}$ give absolute growth of $\pm 12.00-12.80$ gram, $\pm 12.00-12.28$ gram, $\pm 13.10-13.20$ gram, and $\pm 11.10-11.20$ gram, consequently. The absolute growth chart (Figure 2) showed that feed $C$ gives the best response to the freshwater crayfish absolute growth.
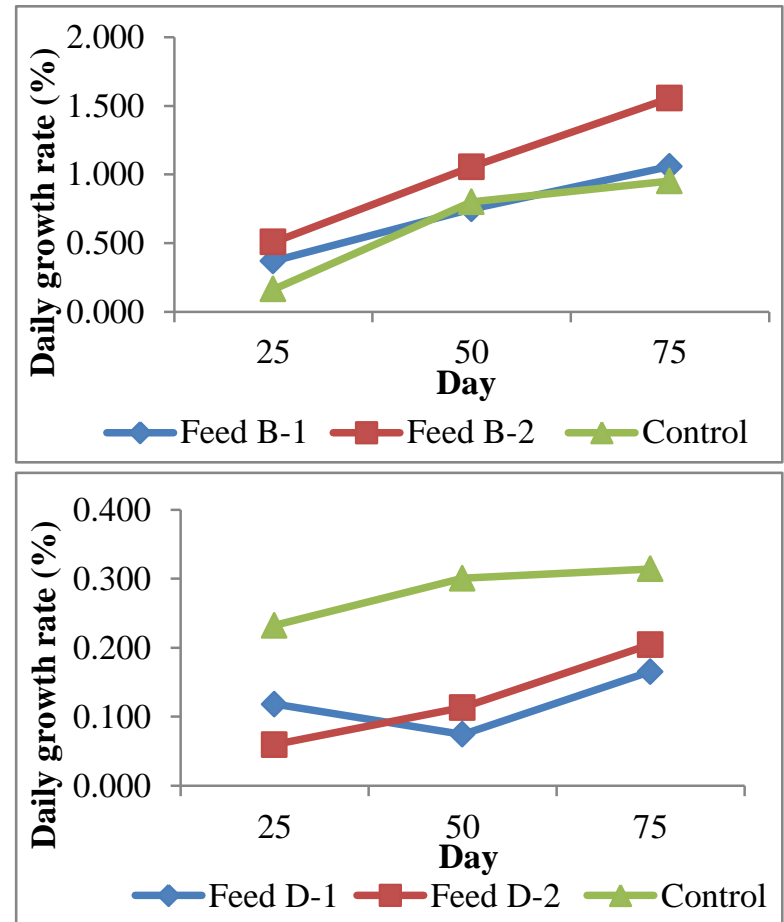

Figure 1. Daily growth rate of freshwater lobster fed enriched feed with lactic acid bacteria.

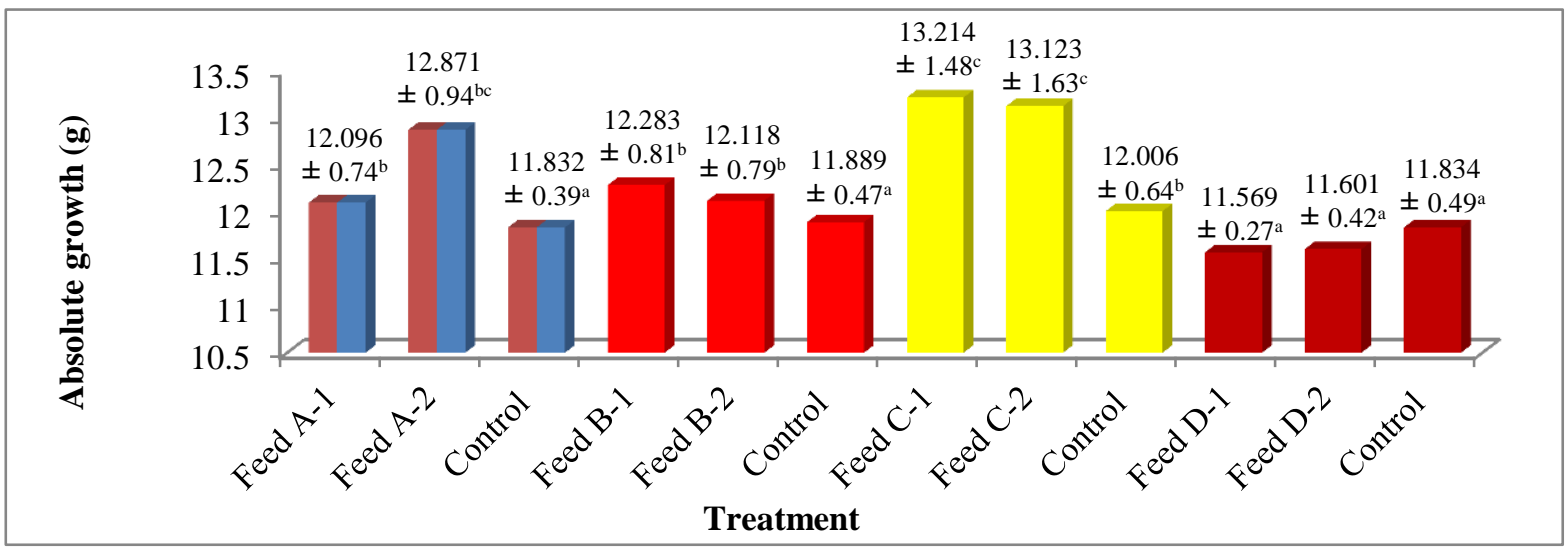

Figure 2. Absolute growth of freshwater lobster fed enriched feed withlactic acid bacteria. Values with the same letter are not significantly different $(\mathrm{P}>0.05)$. 


\section{Discussion}

The feed given with different protein and carbohydrate which was enriched with lactic acid bacteria inoculum can affect the average weight increase and daily growth rate of freshwater crayfish. Highest daily growth rate can be found in Feed C (protein 30\%-carbohydrate 40\%) which was enriched with lactic acid bacteria inoculum $10^{8} \pm$ of $0.22-0.23 \%$. Followed by Feed A (protein 50\%-carbohydrate 20\%) and B (protein 40\%- carbohydrate 30\%) which was enriched by lactic acid bacteria inoculum $10^{8}$ and $10^{10}$, each of it contains of $\pm 0.19-0.20 \%$ and \pm $0.12-0.17 \%$. Meanwhile Feed D does not significantly affect the growth of freshwater crayfish with daily growth rate of $\pm 0.01-0.02 \%$.

In 75 days cultivation, freshwater crayfish which given feed $\mathrm{A}, \mathrm{B}, \mathrm{C}$, and $\mathrm{D}$ give absolute growth of $\pm 12.00-12.80$ gram, $\pm 12.00-12.28$ gram, $\pm 12.10-13.20$ gram, and $\pm 11.10-11.20$ gram consequently. The average absolute growth chart (Figure 2) showed that feed $\mathrm{C}$ gives the best response to the freshwater crayfish absolute growth.

Growth is related to internal and external factor. One of the external factor that highly affects growth is feed (Nisrinah et al, 2013). Growth happens only if the feed consumed contains adequate level of protein. Protein will be used as body builder while fat and carbohydrat are used as energy source. Increased weigh indicates growth, therefore the consumed energy exceeds the main needs (maintenance and other body activities). Another external factor is water quality. The temperature, $\mathrm{pH}$ and ammonia measured during this study were closely related and were within recommended range for the culture of tropical crayfish as described by APHA (1998). Hence, no adverse effect of water quality on the growth of the crayfish.

Generally, carnivora fishes have relatively low activity of amylase enzyme, so the utilization of carbohydrate of feed might be low as well, compared to protein and fat. This leads to the low rate of carbohydrate digestion (Idris, 2016). Feed $\mathrm{C}$ with $30 \%$ protein and $40 \%$ carbohydrate and enriched by bacteria inoculum $10^{8}$ showed the highest growth rate compared to other feeds. It might be caused by the lactic acid bacteria produces enzymes which break carbohydrate into energy source, and increase its digestion and help food absorption process in digestive tract therefore the growth rate increases as well. In addition, the break of carbohydrate becoming a simple glucose accelerate the forming process of lactate in digestive tract, and it depress any potential of other microorganisms growth (Amin and Leksono, 2011). Optimal addition of probiotic could improve the feed quality so it can increase the digestion of the feed, and eventually increase the organisms growth (Irianto 2003; Mansyur and Tangko, 2008).

Feed should contains certain amount of protein and could provide non-protein energy in adequate number therefore it mostly can be used for growth (Aslamyah, 2006). If the energy supply from non-protein is low, protein will be degraded to produce energy, and its funcytion as tissue builder will decrease. Huge amount of energy available in the body will increase the organisms capability to change the energy and store it in the flesh (protein and fat) (Akbar, 2002).

It can be concluded that Feed $\mathrm{C}$ (protein $30 \%$-carbohydrate $40 \%$ ), which enriched by lactic acid bacteria inoculum $10^{8}$ gives the best growth compared to Feed A (protein 20\%-carbohydrate $50 \%$ ), Feed B (protein 40\%- carbohydrate 30\%), and Feed D (protein 20\%-carbohydrate 50\%). Therefore, the addition of amylolytic lactic acid bacteria probiotic into feed with different composition of carbohydrate-protein could stimulate the growth of freshwater crayfish within cultivation period.

\section{Acknowledgement}

We would like to thank Directorate General for Higher Education; Directorate of Research, Technology and Higher Education that has funded this study.

\section{References}

Akbar, A.D. 2002. Effect of flour substitution with cassava flour on feed efficiency and growth of carp (Cyprinus carpio L). Thesis. IPB. Bogor. 43 pp.

Amin and Leksono. 2001. Effectiveness of Lactic Acid Bacteria in inhibiting Bacteria. Airlangga, Yogyakarta.

APHA. 1998. Standar Methods for the Examination of Water and Wastewater. 20th Edition, American Public Health Association. American Water Works Association and water Environmental Federation. Washington DC.

Aslamyah. 2006. Use of Microbial Gastrointestinal Channels as Probiotics to Increase Growth and Survival of Milkfish Fish (Chanos chanos Forsskal). Ph.D Thesis. Bogor Agricultural University.

Effendie, M.I. 1979. Fisheries Biology. Yayasan Pustaka Nusantara, Yogyakarta, 163 p. 
Hasniar and Dahlia. 2016. Screening of Lactic Acid Bacteria (LAB) Amylolytic from Gastrointestinal Freshwater Lobster (Cherax quadricarinatus). J. Galung Tropika, 5(3): $210-218$.

Idris, A.P.S. 2016. Study of protein and utilization on snail mas (Pomacea canaliculata) FPR feed as the source of protein in growth performance of eel Anguilla marmorata. Disertasi. Hassnudin University, Makassar, $188 \mathrm{pp}$.

Irianto, A. 2003. Aquaculture Probiotics. Gadjah Mada University Press, Yogyakarta, 125 p.
Mansyur, A. and A.M. Tangko. 2008. Probiotic: Utilization For Low Quality Fish Food. Media Akuakultur, 2 (2): 145-149.

Nisrinah, Subandiyono, and T. Elfitasari. 2013. The effect of bromelian use on protein feed utilization rate and growth dumbo catfish (Clarias gariepinus). Journal of Aquaculture Management and Technology, 2 (2): 57 - 63.

Wirabakti, M.C. 2006. The growth rate of red tilapia fish (Oreochromis niloticus L) which maintained in Swamp Water with Keramba and Pond System. Journal Tropical Fisheries, $1(1): 61-67$. 